\title{
Perceived Autonomy Support in Primary Education in the Netherlands: Differences between Teachers and Their Students
}

\author{
Wilfried Admiraal ${ }^{1, *}$, Gera Nieuwenhuis ${ }^{2,3}$, Yvette Kooij $^{4}$, Tineke Dijkstra ${ }^{5}, \&$ Ingrid Cloosterman $^{6}$ \\ ${ }^{1}$ Leiden University, Leiden, the Netherlands \\ ${ }^{2}$ Primary school De Grote Beer, The Hague, the Netherlands \\ ${ }^{3}$ Inholland University of Applied Sciences, The Hague, the Netherlands \\ ${ }^{4}$ Leiden University of Applied Sciences, Leiden, the Netherlands \\ ${ }^{5}$ Primary school De Vlieger, The Hague, the Netherlands \\ ${ }^{6}$ Lucas Academy, The Hague, the Netherlands \\ *Correspondence: Leiden University Graduate School of Teaching, Leiden University, Kolffpad 1, 2333 BN Leiden, \\ the Netherlands. Tel: 31-71-527 6080. E-mail: w.f.admiraal@iclon.leidenuniv.nl
}

Received: June 3, $2019 \quad$ Accepted: July 15, $2019 \quad$ Online Published: July 17, 2019

doi:10.5430/wje.v9n4p1 URL: https://doi.org/10.5430/wje.v9n4p1

\begin{abstract}
Student autonomy is a much discussed topic in educational practice and research. In this study, primary school teachers reported what they do to support the autonomy of their students and students mentioned how they perceived autonomy in the classroom. From the findings of a focus group, consisting of 10 teachers from the upper years, six aspects of autonomy were extracted: freedom of choice, self-insight, self-expression, curiosity, independence and problem solving. Then, 77 teachers and 497 students completed a questionnaire with items on these six aspects. This questionnaire study shows that both teachers and students indicated that class work is mostly focused on student independence and the least on freedom of choice. Students and teachers differed in the extent to which this was the case: teachers were much more positive about the extent to which they work on their students' autonomy than their students. This applied to all six distinct aspects of autonomy support.
\end{abstract}

Keywords: autonomy support, primary education, teachers, students

\section{Introduction}

In the Netherlands, student autonomy is in the spotlight in educational policies, research and practice. Teachers are expected to focus not only on all kinds of subject-related goals, but also on pedagogical goals (Onderwijsraad, 2014). Students not only have to acquire math and language skills and knowledge about other school subjects, they also have to learn to make autonomous choices and to take responsibility for these choices. A sense of autonomy seems to have a positive influence on student learning. Vansteenkiste, Zhou, Lens, and Soenens (2005) established that students who experienced a lot of autonomy in the choices they made in their learning process were more concentrated and less distracted during learning, could better plan their learning process, processed the learning content more deeply and took more responsibility for their learning process. The current study focused on the way teachers in upper primary education support the autonomy of their students and how their students experience autonomy in class.

\section{Autonomy Support of Young Students}

The concept of autonomy is part of various views on the motivation of learners for education and learning. Of these, the Self Determination Theory (Self Determination Theory, SDT) of Deci and Ryan (Deci \& Ryan, 1985, 1990, 2000; Ryan \& Deci, 2006) is perhaps the best known in education. SDT is a motivational theory that states that satisfying basic psychological needs of 1) feelings of autonomy 2) feelings of involvement and 3) feelings of competence helps people to develop optimally and feel satisfied. The more these basic needs are satisfied, the more learners are 
intrinsically motivated for their actions. According to the Self Determination Theory, autonomy-supportive authorities (i.e. teachers, parents, mentors) provide their charges as much choice as possible within a specific situation. Students are likely to perceive teachers and the classroom climate as autonomy supportive when teachers provide choices and opportunities for self-expresssion, and explain why learning activities are important. The idea is to help students to connect their sense of self to the activity, so that they can do it with a sense of ownerhship and volition, rather than feeling controlled and coerced by their teachers or parents.

According to research testing the Self Determination Theory in various settings, satisfaction of the three basic psychological needs predicts educational and well-being outcomes by affecting students' motivation (Early et al., 2016; Guay \& Vallerand, 1996; Ryan \& Deci, 2001; Tian, Chen, \& Huebner, 2014; Yu, Li, Wang, \& Zhang, 2016). Many studies (e.g., Hagger, Chatzisarantis, Culverhouse, \& Biddle, 2003; Hardre \& Reeve, 2003; Reeve, Jang, Carrell, Jeon, \& Barch, 2004; Su \& Reeve, 2011) have shown that teachers' autonomy support is related to students' autonomous regulation, perceived competence, and achievement. In their study of 15 high-school mathematics classrooms, Ciani, Middelton, Summers and Sheldon (2010) found that teachers' autonomy support counteracted potential negative implications of emphasizing performance in the classroom. When autonomy support was high, students reported high mastery goals (i.e. the intrinsic motivation to learn amd acquire knowledge and skills), regardless of the teacher's emphasis on performance.

Teachers' autonomy support refers to a group of behaviors that encourage student intrinsic motivation by offering students meaningfull choices, attempting to understand their perspectives, providing them with personally meaningful rationales for task engagement, encouraging their input in decision making processes, and giving them opportunities for self-initiated behavior (Cheon et al., 2019). Stefanou, Perencevich, DiCintio and Turner (2004) distinguish three ways teachers' autonomy support manifests in the classroom: organizational autonomy support, procedural autonomy support and cognitive autonomy support. Organizational autonomy support encourages student ownership of environment and includes teacher behaviors that offer students opportunities for choice over environmental procedures or latitude over rate of progress towards a goal. Students are give opportunities to choose group members, seating arrangements and evaluation procedures, take responsibility of due dates for assignments and participate in creating and implementing classroom rules. Procedural autonomy support encourages student ownership of form, which means that students are given opportunities to choose materials to use in class projects, media to present ideas and the way competence will be demonstrated, display work in an individual manner and discuss their wants. Finally, cognitive autonomy support encourages student ownership of learning and includes teacher behaviors such as asking students to justify or argue for their point, asking students to generate their own problem solving strategies, asking students to evaluate their own and others' solutions or ideas and stimulate students to debate ideas freely.

The limited number of studies in Dutch primary education that have made use of the Self Determination Theory (Stevens \& Borst, 2013; Van der Hoeven, Steenvoorden, \& Verbeeck, 2010; Verbeeck, 2010) generated some empirical evidence for the relationships described above. These authors show that there is a strong connection between feelings of autonomy, involvement and competence, on the one hand, and well-being and an open, involved and healthy functioning in society, on the other. Students' well-being and ongoing development are best served by students' ability to regulate learning processes themselves. In addition, intrinsic motivation is the most desirable condition for deep and successful learning (Stevens \& Borst, 2013; Verbeeck, 2010). Schools could take more account of intrinsic motivation, which is directed from within the learner. Verbeeck (2010) speaks about 'wings', the space for children to go their own way, to be able to make their own choices that suit their needs. Innovative schools give that space by paying attention to basic psychological needs (Van der Hoeven et al., 2010). Learning functions (such as choosing learning objectives, planning for oneself, activating prior knowledge, using feedback, assessing) are then transferred to the students so that they can exert more influence on their own learning process and learning actions. A sense of autonomy therefore seems to have a positive influence on student learning.

Despite the importance attached to student autonomy in both educational research and educational policy, it is not clear how primary school teachers support student autonomy and how students perceive this support. This study focused on teachers' autonomy support in upper primary education in the Netherlands and how their students perceived this autonomy support. The following research questions directed the study:

1) What views do teachers in primary education have on student autonomy?

2) How do teachers describe autonomy support of their students?

3) How do students perceive autonomy support of their teacher? 
4) To what extent do teachers and students differ in the perceived autonomy support of students?

5) What recommendations do teachers have for supporting student autonomy?

\section{Method}

\subsection{Participants}

A total of 87 teachers participated in this study. Ten teachers participated in a focus group, 77 teachers completed an online questionnaire. Of the 77 teachers, 21 teachers indicated that they were willing to administer a paper questionnaire to their students. A total of 497 Grade 4-6 students (aged 10-12 years) completed the questionnaire. The data of 406 students could be linked to 19 teachers; the teachers of the other 91 students did not complete the teacher questionnaire. The data on student autonomy in the classroom was collected in three ways: 1) a focus group meeting with teachers, 2) a teacher questionnaire and 3) a student questionnaire.

\subsection{Focus Group Meeting}

A focus group has been organized with ten teachers from primary schools that are affiliated with one consortium of primary schools in the Hague in the Netherlands. The aim of this focus group meeting was to define the concept of autonomy from a practical perspective. We argue that existing instruments such as the Learning Climate Questionnaire of Black and Deci (2000) do not provide enough variety in ways primary school teachers can support student autonomy. The ten teachers have been approached personally by the authors and worked at a Jenaplan school or Montessori school (both school types with a focus on student autonomy) or at a regular primary school. The aim of the focus group was to gather information about how teachers understand student autonomy, what they undertake to support and enhance that autonomy and what opportunities and threats they perceive. The results of the focus group were used to develop the questionnaire items. The results in a first group session with the authors were clustered into a number of aspects of autonomy. In a subsequent group session, the number of clusters was reduced to six aspects of student autonomy: 1) freedom of choice (e.g., setting one's own goals, setting one's own time, and setting out one's own learning path), 2) self-insight (e.g., understanding why s/he is doing something, knowing when s/he needs help and dares to ask for it), 3) self-expression (e.g., responsibility for own learning process, self-awareness, and being open, assertive, smart, and not easy to distract), 4) curiosity (e.g,, wanting to learn, having fun in school, and being intrinsic motivated for schooling), 5) independence (e.g., promoting independence by planning the subject matter) and 6) problem solving (e.g,, working through a particular strategy to a solution).

\subsection{Questionnaire for Teachers and Students}

Following the second meeting of the focus group, the authors formulated items for each of the six aspects. After a process of formulation and reformulation, the teacher questionnaire was first developed. After this, the student questionnaire was developed, with the wording "In my class my students ..." from the teacher questionnaire replaced by "In class we ..." in each item. Both student and teacher questionnaire are included in the Appendix. In the Appendix, we also indicate which item belongs to which of the six aspects of autonomy. After reliability analysis based on both teacher data and student data, two items have been removed, one from the aspect of Freedom of choice and one of the aspect Self-insight, to arrive at homogeneous sets of items. The reliability as well as the mean scores and standard deviations for each of the six aspects in both the teacher questionnaire and student questionnaire are included in Table 1. Directly following these pre-structured items, the teachers were presented three open questions: 1) "What is your understanding of student autonomy?" 2) "How do you promote student autonomy in your class?" and 3) "In an ideal situation, what would you like to do differently when it comes to promoting student autonomy?". These questions were answered by 60 (Open question 1), 63 (Open question 2) and 61 (Open question 3) teachers, respectively.

\subsection{Data Analyses}

Descriptive statistics were used to analyze the quantitative data. To test the difference between the scores of teachers and those of their students, the scores of the students are aggregated to the teacher about whom each item has been scored. This means that we have a minimum of 5 and a maximum of 31 student scores for each teacher (mostly between 20 and 30). Subsequently, a pairwise t-test was performed on the mean scores of teachers and student groups on the six aspects.

Content analysis was used to analyze the qualitative data of the open questions. Each author has analyzed a different part of the qualitative data, with an overlap. In addition, the teachers' answers to the open questions were coded as one of the six aspects of the questionnaire. The results of the content analysis were discussed in the research team 
and only included in this manuscript if there was consensus.

\section{Results}

\subsection{Teachers' Views on Student Autonomy}

The analysis of the answers to the first open question shows that teachers differed in the extent to which they considered the autonomy of students in primary education important. Some teachers believed that students can handle more autonomy than teachers often think: "Students can handle more space, can collaborate more, discover for themselves, and consult each other" [Grade-6 teacher]. Other teachers indicated that still much needs to be done in primary education to promote and support autonomy, but that there are also clear limits to this: "Children cannot always choose for themselves, there are also things that need to be done they may feel less inclined to" [Grade- 5 and 6 teachers]. Yet teachers considered student autonomy very important in general and in the upper-grades where students are prepared for secondary education, in particular.

To be autonomous in the classroom, students must have freedom of choice to some extent. Not all teachers dared to give students this freedom. They indicated that it is difficult to decide for this, but when they do try it, they are often surprised by the long-term results: "In the beginning, the students experience autonomy as freedom, happiness and the results decrease slightly, but later these increase more than they had decreased" [Grade-5 teacher]. In general, most teachers believed that students have too few opportunities to direct their own learning paths. They indicated that as teachers they are stuck to certain frameworks and that students are required to do a lot, but it is not always clear to them why this is really necessary.

Teachers mentioned that all children should have self-insight to some extent so that they have a picture of their own functioning and realize what qualities they possess. This way, students can work on aspects that they themselves see to be further developed. A Grade-4 teacher indicated that she finds it important to involve students in her teaching approach: "They can easily articulate what works for them."

Another Grade-4 teacher reported that it is important that students are noticed and listened to as much as possible, so that they have room to express themselves: "Students are willing to do a lot if they only feel that their opinion matters". Two Grade-5 teachers have linked their perceptions of importance of autonomy to curiosity. According to them, children are curious by nature: "They want to know why something is necessary, or why something is allowed." According to these teachers, supporting curiosity helps students to become enthusiastic about learning and to give them self-confidence.

The aspect of independence is most frequently mentioned, together with freedom of choice, in the answers to this question. The teachers perceived being independent and responsible for their own tasks an essential qualities of young children. According to them, it is an important basis to develop as an independent individual. Students must be guided by their teachers in becoming independent and making choices themselves. Students need, according to the teachers in this study, a different degree of guidance in the development of independence. They found it difficult to shape that in class, but they still believed it is very important. Independence is also something that students have to learn to deal with and that is easier for one student than for another. According to the teachers from the current study, the home situation can also play a role. Some children have more room to be independent at home than others. In order to prepare the students well for secondary education, the teachers considered it important to develop a high degree of independence among the children so that they can cope with changes and demands, and manage their own development. This is particularly important in the upper grades of primary education, where the entrance to secondary education is being prepared.

Being aware of different learning processes can support the students in problem solving. One of the teachers reported:

I think it is important that children are aware of the different learning processes in order to complete an assignment. As a teacher we also have to offer that space [to find a solution in different ways.], yet children must learn this. Just as we have to teach students that one can make mistakes and that one can learn from this. This ensures that students look more consciously at their learning approach, so that they will no longer make the same mistakes next time [Grade- 6 teacher].

According to the teachers, the students themselves will look for other solutions: "If you can trust yourself and have learned to solve problems yourself, you can grow and develop", according to Grade-5 teacher. 


\subsection{Teachers' Perceived Autonomy Support}

Table 1. Mean Scores (M), Standard Deviations (SD) and Reliability (Cronbachs $\alpha$ ) for Each of the Six Autonomy Scales in the Teacher Questionnaire and Student Questionnaire

\begin{tabular}{llllllll}
\hline & \multicolumn{3}{c}{ Teachers (N=77) } & \multicolumn{3}{c}{ Students (N=497) } \\
\cline { 2 - 7 } $\begin{array}{l}\text { Aspects of autonomy } \\
\text { (number of items) }\end{array}$ & $M$ & $S D$ & $\alpha$ & $M$ & $S D$ & $\alpha$ \\
\hline Freedom of choice (7) & 2.61 & 0.74 & 0.85 & 2.42 & 0.75 & 0.75 \\
Self-insight (6) & 3.65 & 0.61 & 0.75 & 3.10 & 0.70 & 0.61 \\
Self-expression (5) & 3.51 & 0.58 & 0.64 & 3.13 & 0.81 & 0.63 \\
Curiosity (6) & 3.30 & 0.61 & 0.79 & 3.05 & 0.75 & 0.67 \\
Independence (6) & 4.05 & 0.51 & 0.68 & 3.74 & 0.64 & 0.61 \\
Problem solving (7) & 3.65 & 0.59 & 0.75 & 3.43 & 0.66 & 0.60 \\
\hline
\end{tabular}

In Table 1, we summarize the quantitative results of the questionnaire. These results show that teachers mainly focused on supporting the independence of their students, promoting self-insight (such as discussing with students what they can do well, what they find difficult or why they are asked to do something) and encouraging problem-solving behavior of their students (let students in the classroom think of solutions to problems or let them first try to solve something themselves if they have questions). According to their own reports, teachers work less on the freedom of choice of their students.

Teachers' statements to the second open question are also arranged according to the six aspects of autonomy as listed in Table 1. The teachers mentioned as part of their autonomy support offering their students freedom of choice. To encourage children to make choices, they are also expected to respect choices of others. This can be established by providing students room to apply their own ideas, to choose their own learning activities and plan these accordingly. Teachers stated that making choices is a learning process that the teachers scaffold with first directing students and then providing them with more freedom to choose. Although teachers agreed it is important to give students some freedom, they also reported that it is essential to set rules and limits, and to provide a well-structured positive learning environment. The options students can choose from are at different levels. For example, children can sometimes choose which assignment they will do: "During independent work, the children can determine their own work. There are a number of assignments that have to be completed, but students can choose from a number of other assignments" [Grade-5 teacher]. Another example is that students are free to choose to participate in instructional activities: "I try to give them options within my instruction, which already differentiates between different ability levels" [Grade-6 teacher]. Other examples are that students sometimes can determine the pacing or sequence of items, or that they can choose to work individually or together with their peers.

According to the teachers, self-insight can be encouraged during conversations between teacher and students to stimulate students to think about their learning process. The objectives of lessons can be discussed as well as teacher reflections on students' report cards, their individual plans and test results, completed assignments and their ideas about the school subject and learning activities. The teachers perceived these reflective activities to be important because these trigger children to think about their abilities and their learning process. "This also teaches children how to make connections between what is required and what they are able to," reported one Grade- 5 teacher. In the daily practice of the teachers who have completed the questionnaire, much use is made of particular tools, which they believe promote the autonomy of students. Task cards are often mentioned, in the form of a day or week task. These task cards create time to practice difficult learning material amd to work on additional tasks and self-selected goals.

The interventions that teachers reported to support the autonomy of their students stimulate the formation of students' own opinion. Children learn that it is good to have their own opinion and that they are allowed to speak out. This kind of self-expression is promoted by regularly asking students for their opinion and their reasoning. Children develop their own self. They develop self-knowledge and discover qualities and peculiarities of themselves. In this way, they learn to set their own goals. Critical thinking is encouraged as well as thinking outside the box. The role of the teacher is important, according to the teachers. They encourage reflection by having conversations with children focusing on processes and less on learning outcomes.

The teachers reported that in promoting children's autonomy, they connect as much as possible with the interests of the children, while encouraging students' own input and ideas. Working on projects is a way to enhance students' curiosity. Working on speaking engagements, book reviews and presentations are also mentioned as suitable work 
forms. Some teachers start from the students' own research questions. A rich variety of materials that are challenging promote children to discover and develop their talents.

Independence is regularly mentioned with respect to autonomy support. A Grade-4 teacher mentioned that working independently must be taught. Promoting independence places demands on the organizational talent of the teacher, according to several teachers. A well-structured learning environment and clear rules are mentioned as important as well: "... so that everyone knows what is expected and what the rules are like"[Grade-5 teacher]. According to the teachers, various forms of collaborative learning can be applied to promote independence, which stimulate discussions, consultations and helping behavior. Children can choose with whom they work or sometimes poor-performing students are linked to high-performing students. In order to stimulate collaboration, teachers use work forms and assignments that are deliberately designed to trigger collaboration and communication amongst peers.

Independence is associated by many teachers with problem solving. The teachers reported that they let the students solve their task problems themselves as much as possible. Children are encouraged to ask each other for help, search for their own answers and have conversations about how to solve a problem: "... by discussing many situations with them and how they can handle situations. We sometimes discuss this prior to a task and sometimes also afterwards" [Grade-6 teacher].

\subsection{Students' Perceived Autonomy Support}

In Table 1, we summarized the results of the student questionnaire. Students also indicated that in class their independence is mostly supported and freedom of choice the least. The difference in mean scores between teachers and students is significant for all scales of autonomy ( $>.05$ ), with higher scores for teachers. This means that teachers think significantly more positively about supporting students' autonomy than students about the extent to which they actually experience autonomy in the classroom. This is especially true for working on self-insight of students (e.g., discussing with students what they are good at, what students find difficult or why they should do something) and encouraging students' self-expression (e.g., students are allowed to tell what they think and feel, to give their opinion and say 'no' if they do not want to do something). Yet the differences between teachers and students with regard to the other four aspects of student autonomy are also considerable. In Table 2, we summarize the data of 19 teachers and their students.

Table 2. Mean scores (M), Standard Deviations (SD), and Effect Size of the Difference in Mean Scores of Teachers and Students (Cohens d). For the latter, $\mathrm{d}<0.30=$ Small Difference, $0.30 \leq \mathrm{d} \leq 0.80=$ Medium Difference and $\mathrm{d}>$ $0.80=$ Large Difference (see Cohen, 1988).

\begin{tabular}{|c|c|c|c|c|c|}
\hline \multirow[b]{2}{*}{$\begin{array}{l}\text { Aspects of autonomy } \\
\text { (number of items) }\end{array}$} & \multicolumn{2}{|c|}{ Teachers $(\mathrm{N}=19)$} & \multicolumn{2}{|c|}{ Students $(\mathrm{N}=406)$} & \multirow[t]{2}{*}{ Cohens d } \\
\hline & $M$ & $S D$ & $M$ & SD & \\
\hline Freedom of choice (7) & 2.81 & 0.86 & 2.36 & 0.53 & 0.63 \\
\hline Self-insight (6) & 3.59 & 0.64 & 3.09 & 0.32 & 0.99 \\
\hline Self-expression (5) & 3.59 & 0.62 & 3.14 & 0.36 & 0.89 \\
\hline Curiosity (6) & 3.35 & 0.74 & 3.05 & 0.29 & 0.53 \\
\hline Independence (6) & 4.04 & 0.59 & 3.74 & 0.24 & 0.67 \\
\hline Problem solving (7) & 3.92 & 0.66 & 3.39 & 0.35 & 1.00 \\
\hline
\end{tabular}

Paired t-tests show that this group of students also indicates a significantly lower score than their teachers on all aspects of autonomy. Teachers are more positive than their students with regard to the freedom of choice they facilitate $(\mathrm{t}(18)=3.23 ; \mathrm{p}=.005)$, supporting self-insight $(\mathrm{t}(18)=3.87 ; \mathrm{p}=.001)$, the extent to which they try to support students in their self-expression $(\mathrm{t}(18)=3.51 ; \mathrm{p}=.003)$, the support of curiosity of their students $(\mathrm{t}(18)=$ $2.15 ; \mathrm{p}=.046)$, the extent to which they try to promote student independence $(\mathrm{t}(18)=2.41 ; \mathrm{p}=.027)$, and the attention they give to problem solving $(\mathrm{t}(18)=4.66 ; \mathrm{p}<.001)$. The differences between the experiences of teachers and their students are considerable: for three aspects there are medium differences (Freedom of choice, Curiosity and Independence) and for the other three aspects large differences (Self-insight. Self-expression and Problem solving).

\subsection{Recommendations for Supporting Student Autonomy}

The answers to the third open question ("In an ideal situation, what would you like to do differently when it comes to supporting student autonomy?") are summarized with a number of recommendations. Most of the teachers' 
recommendations in the survey are provide for supporting freedom of choice, self-insight, self-expression and curiosity; no recommendations were provided with regard to the other two aspects of autonomy support. A reason for this may be that the teachers feel that they are already paying a lot of attention to these latter aspects in the classroom and that they do not want to do this differently.

Three types of recommendations with respect to freedom of choice are provided by the teachers. First, some teachers mentioned that they would give students more freedom of choice by allowing them to choose the sequence in which they work on their assignments and give the students time to plan their work themselves. Second, some teachers reported that they would go beyond freedom of choice for just items sequencing by providing students a voice in what they want to learn by setting goals together with the teacher. It is then necessary for the children to have an idea of what they can and cannot do well independently. Third, a few teachers reported that they would give the students more choice in how content is learned, aligning the learning style and interests of the students. They would like to detach from the standardized methods and let students choose how they want to learn. According to the teachers, these recommendations fit the ideal situation to support the autonomy of students. Yet more suitable teaching materials, proper workplaces, more time and 'more hands' in class would be necessary.

Teachers mentioned that when children are allowed to choose more what they want to learn and in what way, it is important that they know what they are able to. Teachers have to organize enough possibilities for students to reflect on their own knowledge and skills so that they gain more self-insight.

Teachers provided some recommendations to support students' self-expression, which were all about providing students a voice in learning, teaching and assessment. One recommedation included that teachers should schedule time for individual conversations with their students so that students can indicate what and how they want to learn. Another recommendation was to give students more opportunities to show their knowledge and skills by, for example, assess learning processes and outcomes with a portfolio in which the children show their work.

Teachers offered several recommendation to support and stimulate the curiosity of their students. Teachers reported that they have to think much more from the perspective of the children and less from what should be done or what should be learned. When students can work on self-conceived topics and projects, curiosity is supported and encouraged. A Grade-4 teacher mentioned: "I would like to give children two hours each week for talent development. That they can get started with a subject or project they have devised to make better use of their talents." Two types of recommendations for teaching included the educational materials used in class and how teachers interact with their students. Materials must be challenging, stimulating students to get started. This includes ICT materials and visual materials, but also (working) corners that support different work forms. Students could also be supported to work on assignments outside school. With respect to teacher-student interaction, teachers reported that they explore research questions with their students and to ask provocative questions to trigger their curiosity.

\section{Discussion and Conclusion}

In this study, both teachers and primary school students indicated how much attention teachers give to six aspects of student autonomy: freedom of choice, independence, self-insight, self-expressions, problem solving and curiosity. These six aspects can be related to the three ways of autonomy support Stefanou et al. (2004) distinguished. Freedom of choice and independence are primarily related to student ownership of environment (organizational autonomy support); self-insight and self-expression mainly refer to student ownership of form (procedural autonomy support) and problem solving and curiosity can be related to student ownership of learning (cognitive autonomy support). Students' independence received the most attention compared to the other five aspects; Freedom of choice the least. These two aspects are also most frequently cited as a characteristic of student autonomy, but teachers indicate that it is difficult to give their students a great deal of freedom of choice and thus to hand over the management of the learning process. Teachers and their students differed strongly about the extent to which attention is paid to the six aspects of autonomy: Teachers were much more positive about what they do in the classroom to support their students' autonomy compared to students' feeling of autonomy in class. In addition, teachers indicated that they want to adjust their pedagogical-didactical actions, especially with regard to supporting freedom of choice for students and stimulating students' curiosity. These findings are in line with the literature on student autonomy in which freedom of choice is central (Patall, Vasquez, Steingut, Trimble, \& Pituch, 2016; Van der Hoeven et al., 2010; Verbeeck, 2010). However, the study also indicates that teachers feel uncertain about how much freedom of choice students should be given and how this should be done. Van der Hoeven et al. (2010) agree that adults are rather critical of students making their own choices, because they often have the impression that students only do the activities they like. Teachers who respect student autonomy are likely to make it easier for students to make their own choices because 
these teachers have less need to control everything (Stevens \& Borst, 2013).

\subsection{Limitations and Directions for Future Research}

The teachers who participated in this study did this voluntarily. This may have led to a relatively positive image that they have of the extent to which they support the autonomy of their students. But that could also mean that their students have a relatively positive view of the autonomy they get in the classroom from their teachers. Nevertheless, the differences in perception of autonomy between teachers and students were considerable.

A second comment that we want to make in this study is the use of a questionnaire among students in primary education (upper grades). Only 19 of the 77 teachers have administered the student questionnaire. The reason for this has not been investigated. In addition, although we have tried to formulate the items from the questionnaire in such a way that they can be well understood and accurately completed by primary school students, they may have interpreted the items differently from their teachers. An example is the item "In my class, my students can choose in which sequence they do their work" (Teacher questionnaire) and "We can choose in which sequence we do our work" (Student questionnaire). It is possible that teachers limit 'work' to specific assignments or projects, while students may interpret 'work' more broadly. Additional interviews with teachers and students who had completed the questionnaire could have provided more clarity about a possible difference in interpretations.

A third comment is that there is some evidence that teachers generally do no distribute autonomy support in an equal way across students, which might lead to unfavourable educational and well-being outcomes, compared to perceptions of equal autonomy support (Chatzisarantis, Nilay Ada, Ahmadi, Caltabiano, Wang, Thogersen-Ntoumani, \& Hagger, 2019). Although in the current study the difference between students in their perceptions of autonomy support were quite small (with rather low standard deviations for each scale), these differences in student perceptions might be a promising future research direction.

\subsection{Concluding Remarks}

In conclusion, the present study extends previous research with more details about teachers' and students' perceptions of autonomy support in primary school classes. Teachers appeared to be much more positive about their autonomy support than their students, and various implications for autonomy support are presented. More explicit attention for autonomy support in class might help students to recognize teachers' efforts in this and to identify their own role in the regulation of their learning processes, which might also results in increased engagement with school and learning.

\section{References}

Black, A. E., \& Deci, E. L. (2000). The effects of instructors' autonomy support and students' autonomous motivation on learning organic chemistry: A self-determination theory perspective. Science Education, 84, 740-756. https://doi.org/10.1002/1098-237X(200011)84:6<740::AID-SCE4>3.0.CO;2-3

Chatzisarantis, N. L. D., Nilay Ada, E., Ahmadi, M., Caltabiano, N., Wang, D., Thogersen-Ntoumani, C., \& Hagger, M. S. (2019). Differential effects on perceptions of equal, favourable and unfavourable autonomy support on educational and well-being outcomes. Contemporary Educational Psychology, 58, 33-43. https://doi.org/10.1016/j.cedpsych.2019.02.002

Cheon, S. H., Reeves, J., Lee, Y., Ntoumanis, N., Gillet, N., Kim, B. R., \& Song, Y. G. (2019). Expanding autonomy psychological need states from two (satisfaction, frustration) to three (dissatisfaction): A classroom-based intervention study. Journal of Educational Psychology, 111, 685-702. https://doi.org/10.1037/edu0000306

Ciani, K. D., Middleton, M. J., Summers, J. J., \& Sheldon, K. M. (2010). Buffering against performance classroom goal structures: The importance of autonomy support and classroom community. Contemporary Educational Psychology, 35, 88-99. http://dx.doi.org/10.1016/j.cedpsych.2009.11.001

Cohen, J. (1988). Statistical power analysis for the behavioural sciences (2nd ed.). Hillsdale, NJ: Lawrence Erlbaum Associates.

Deci, E. L., \& Ryan, R. M. (1985). The general causality orientations scale: Self-determination in personality. Journal of Research in Personality, 19, 109-134. https://doi.org/10.1016/0092-6566(85)90023-6

Deci, E. L., \& Ryan, R. M. (1990). A motivational approach to self: Integration in personality. In R. Dienstbier (Ed.), Nebraska symposium on motivation. Perspective on motivation (Vol. 38, pp. 237-288). Lincoln, NE: University of Nebraska Press. 
Deci, E. L., \& Ryan, R. M. (2000). The "what" and "why" of goal pursuits: Human needs and the self-determination of behavior. Psychological Inquiry, 11, 227-268. https://doi.org/10.1207/S15327965PLI1104_01

Early, D. M., Berg, J. K., Alicea, S., Si, Y., Aber, J. L., Ryan, R. M., \& Deci, E. L. (2016). The impact of every classroom, every day on high school student achievement: Results from a school-randomized trial. Journal of Research on Educational Effectiveness, 1, 3-29. https://doi.org/10.1080/19345747.2015.1055638

Guay, F., \& Vallerand, R. J. (1996). Social context, student's motivation, and academic achievement: Toward a process model. Social Psychology of Education, 1, 211-233. http://dx.doi.org/10.1016/j.cedpsych.2013.07.005

Hagger, M. S., Chatzisarantis, N. L. D., Culverhouse, T., \& Biddle, S. J. H. (2003). The processes by which perceived autonomy support in physical education promotes leisure-time physical activity intentions and behavior: A transcontextual model. Journal of Educational Psychology, 95, 784-795. https://doi.org/10.1080/08870440801956192

Hardre, P. L., \& Reeve, J. (2003). A motivational model of rural students' intentions to persist in, versus drop out of, high school. Journal of Educational Psychology, 95, 347-356. http://dx.doi.org/10.1037/0022-0663.95.2.347

Onderwijsraad. (2014). Een eigentijds curriculum [A contemporary curriculum]. The Hague, the Netherlans: Onderwijsraad.

Patall, E. A., Vasquez, A. C., Steingut, R. R., Trimble, S. S., \& Pituch, K. A. (2016). Daily interest, engagement, and autonomy support in the high school science classroom. Contemporary Educational Psychology, 46, 180-194. http://dx.doi.org/10.1016/j.cedpsych.2016.06.002

Reeve, J., Jang, H., Carrell, D., Jeon, S., \& Barch, J. (2004). Enhancing students' engagement by increasing teachers' $\begin{array}{lllll}\text { autonomy support. } & \text { Motivation and }\end{array}$ https://doi.org/10.1023/B:MOEM.0000032312.95499.6f

Ryan, R. M., \& Deci, E. L. (2001). On happiness and human potentials: A review of research on hedonic and eudaimonic well-being. In S. Fiske (Ed.)., Annual review of psychology (pp. 141-166). Palo Alto, CA: Annual Reviews, Inc. https://doi.org/10.1146/annurev. psych.52.1.141

Ryan, R. M., \& Deci, E. L. (2006). Self-determination and the problem of human autonomy: Does psychology needs choice, self-determination, and will? Journal of Personality, 74, 1557-1586. https://doi.org/10.1111/j.1467-6494.2006.00420.x

Stefanou, C. R., Perencevich, K. C., DiDintio, M., \& Turner, J. C. (2004). Supporting autonomy in the classroom: Ways teachers encourage student decision making and ownership. Educational Psychologist, 19(3), 97-110. https://doi.org/10.1207/s15326985ep3902_2

Stevens, L., \& Borst, G. (red.) (2013). Pedagogisch Tact: Op het goede moment het juiste doen, óók in de ogen van de leerling [Pedagogical tactfulness: Doing the right thing at the right moment, also in the eyes of the children]. Antwerp-Apeldoorn, Belgium-the Netherlands: Garant.

$\mathrm{Su}$, Y., \& Reeve, J. (2011). A meta-analysis of the effectiveness of intervention programs designed to support autonomy. Educational Psychology Review, 23, 159-188. https://doi.org/10.1007/s10648-010-9142-7

Tian, L., Chen, H., \& Huebner, S. E. (2014). The longitudinal relationships between basic psychological needs satisfaction at school and school- related subjective well-being in adolescents. Social Indicators Research, 119, 353-372. https://doi.org/10.1007/s11205-013-0495-4.

Van der Hoeven, J., Steenvoorden, M., \& Verbeeck, K. (2010). Wie de schoen past ...Het belang van de klik tussen leerlingen en school [Who fits the shoe... The importance of a fit between students and school]. 's-Hertogenbosch, the Netherlands: KPC Groep.

Vansteenkiste, M., Zhou, M., Lens, W., \& Soenens, B. (2005). Experiences of autonomy and control among Chinese learners: Vitalizing or immobilizing? Journal of Educational Psychology, 97, 468-483. http://dx.doi.org/10.1037/0022-0663.97.3.468

Verbeeck, K. (2010). Op eigen vleugels. Autonomie voor kinderen in het basisonderwijs[On its own wings. Student autonomy in primary education]. 's-Hertogenbosch: KPC Groep.

Yu, C., Li, X., Wang, S., \& Zhang, W. (2016). Teacher autonomy support reduces adolescent anxiety and depression: An 18-month longitudinal study. Journal of Adolescence, 49, 115-123. https://doi.org/10.1016/j.adolescence.2016.03.001 


\section{Appendix: Teacher and student questionnaire Autonomy support}

In the final questionnaire, the items are arranged randomly referring to Freedom of choice (Items 1-8), Self-insight (Items 9-15), Self-expression (Items 16-20), Problem solving (Items 21-27), Curiosity (Items 28-33) and Independence (Items 34-39). All items are answered on a 5-point Likert type scale with $1=$ (Almost) never, $2=$ Sometimes, $3=$ Quite often, $4=$ Very often and $5=$ (Almost) always.

\section{Teacher items}

In my class .......

1. My students can choose to do their work individual or together.

2. My students can decide what to do when they have completed an assignment

3. My students can choose the sequence in which they do their work.

4. My students can choose which materials they use.

5. My students can decide how long they work on a task.

6. My students can choose where they work.

7. My students can decide what they want to learn.

8. My students can choose whether to participate in the instructional activities.

9. I discuss with my students what they can do well.

10. I discuss with my students what they find difficult.

11. I discuss their work with my students.

12. I explain why my students have to do something.

13. I discuss school reports or portfolios with my students.

14. I let students think first before they start doing something.

15. My students are allowed to explain why they do something in a certain way.

16. My students are allowed to tell what they think and feel.

17. My students are allowed to say "no" if they don't want to do something.

18. My students can present their work to the group.

19. My students can speak out if they have a different opinion from others.

20. I ask my students for their opinion.

21. It's okay to make mistakes.

22. My students can come up with solutions themselves if something fails.

23. My students ask classmates for help if they don't know something.

24. My students are allowed to discuss while working.

25. Together we come up with solutions to problems.

26. We look together for an answer if I don't know an answer.

27. My students must try to solve their questions themselves.

28. I try to make my students curious.

29. I ensure that there is much to be found that interests my students.

30. My students can learn the things that they find interesting.

31. I take into account the interests of my students.

32. I try to provide variety in teaching forms.

33. I try to tell in a captivating way.

34. My students can find something easily when they need it.

35. I try to get my students to work independently. 
36. I try to let my students work undisturbed.

37. It is clear where everything is.

38. I try to be clear about what my students should do in class.

39. My students can do things themselves.

The open questions:

40. What do you think about the autonomy of pupils in primary education?

41. In what ways do you try to promote the autonomy of the students in your class?

42. In the ideal situation, what would you like to do differently in relation to promoting the autonomy of your students?"

\section{Student items}

In class ......

1. We can choose to do our work individual or together.

2. We can decide what to do when we have completed an assignment

3. We can choose the sequence in which we do our work.

4. We can choose which materials we use.

5. We can decide how long we work on a task.

6. We can choose where we work.

7. We can decide what we want to learn.

8. We can choose whether to participate in the instructional activities.

9. The teacher discusses with us what we can do well.

10. The teacher discusses with us what we find difficult.

11. The teacher discusses our work with us.

12. The teacher explains why we have to do something.

13. The teacher discusses report vards or portfolios with us.

14. The teacher let us think first before we start doing something.

15. We are allowed to explain why we do something in a certain way.

16. We are allowed to tell what we think and feel.

17. We are allowed to say "no" if we don't want to do something.

18. We can present our work to the group.

19. We can speak out if we have a different opinion from others.

20. The teachers asks us for our opinion.

21. It's okay to make mistakes.

22. We can come up with solutions ourelves if something fails.

23. We ask classmates for help if we don't know something.

24. We are allowed to discuss while working.

25. Together we come up with solutions to problems.

26. We look together for an answer if I don't know an answer.

27 . We must try to solve our questions ourselves.

28. The teacher tries to make us curious.

29. The teacher ensures that there is much to be found that interests us.

30. We can learn the things that we find interesting. 
31. The teachers takes into account our interests.

32. The teacher tries to provide variety in teaching forms.

33. The teacher tries to tell in a captivating way.

34. We can find something easily when we need it.

35 . The teacher tries to get us to work independently.

36. The teacher tries to let us undisturbed.

37. It is clear where everything is.

38. The teacher tries to be clear about what we should do in class.

39. We can do things for ourselves. 